\title{
Morphology, molecular identification, and pathogenicity of Vibrio spp. on blood clam (Anadara granosa) in Yogyakarta, Indonesia tourism beach areas
}

\author{
ANNA ROOSIANA DEVI, ARI SUSILOWATI", RATNA SETYANINGSIH \\ Bioscience Study Program, Graduate Program, Universitas Sebelas Maret. Jl Ir. Sutami 36 A, Kentingan, Surakarta 57126, Central Java, Indonesia. \\ Tel./fax.: +62-271-663375, "email: arisusilowati@ staff.uns.ac.id
}

Manuscript received: 13 June 2019. Revision accepted: 8 August 2019.

\begin{abstract}
Devi AR, Susilowati A, Setyaningsih R. 2019. Morphology, molecular identification, and pathogenicity of Vibrio spp. on blood clam (Anadara granosa) in Yogyakarta, Indonesia tourism beach areas. Biodiversitas 20: 2890-2896. Seafood is very popular among Indonesian people, especially in coastal areas. In Bantul Yogyakarta, blood clams have become one of tourist's favorite, either cooked or raw. Blood clams are filter feeders that cause the clams to be vulnerable to contamination of pathogenic bacteria that can cause foodborne disease, including Escherichia, Pseudomonas, and Vibrio. The 10-20\% cases of foodborne disease transmitted through seafood caused by Vibrio spp. Three species of Vibrio can cause foodborne disease in humans, i.e., V. cholerae, V. parahaemolyticus, and $V$. vulnificus. The purpose of this study was to determine the character of Vibrio using morphological and molecular identification and pathogenicity on blood clam (Anadara granosa). Blood clams samples were collected from Depok, Goa Cemara, and Kwaru beaches in Bantul, Yogyakarta, Indonesia. Isolation of Vibrio spp. from blood clams was done using selective differential Thiosulfate Citrate bile salts sucrose (TCBS) culture medium. The morphological characters of the isolate colonies were determined based on the color, shape, texture, and size of the colony. Hemolysis test was also performed to evaluate the pathogenicity by using blood agar media. Molecular identification of Vibrio species was made using 16S rRNA sequence. Phylogenetic analysis was performed using Neighbor-Joining method in Mega X software. Samples for the analysis came from DNA sequences of this study and those from the GenBank database. Of the total 15 isolates obtained, four isolates showed positive $\beta$-hemolysis, namely, isolate $\mathrm{P}_{2} \mathrm{~S}_{2}-1 \mathrm{bH}, \mathrm{P}_{3} \mathrm{~S}_{1}-1 \mathrm{aH}, \mathrm{P}_{2} \mathrm{~S}_{1}-1 \mathrm{aK}$ and $\mathrm{P}_{2} \mathrm{~S}_{2-}$ $1 \mathrm{aK}$, and one isolate had positive $\alpha$-hemolysis $\left(\mathrm{P}_{3} \mathrm{~S}_{2}-1 \mathrm{aK}\right)$. Seven species of Vibrio were identified as $V$. algynolyticus, $V$. parahaemolyticus, V. diabolicus, Vneocaledonicus, V. azureus, V. natrigens, and V. cholerae.
\end{abstract}

Keywords: 16S rRNA, blood clams, molecular identification, morphology, molecular, Vibrio

\section{INTRODUCTION}

Seafood is very popular within the coastal, especially in seaside tourism areas. One of the famous tourism side in Indonesia that still shows massive improvement as a tourist destination is the beach area in Bantul, Yogyakarta. One of the most favorites is culinary. The shellfish is obtained directly from fishermen and breeder who live around the coastal area, and some were supplied from outside the city due to the lack of shellfish breeder in the area.

Fresh raw blood clams have nutritional values, including protein $19.48 \%$, fat $2.50 \%$, water $74.3 \%$, and ash $2.24 \%$ (Nurjanah 2005). Although blood clams are rich in protein, if they are not adequately processed before consumption, they are contaminated by microorganisms that are dangerous for human health. Blood clams are filter feeders which filter to get food so that the clams are easy to get contaminated with microorganisms and can lead to the emergence of foodborne disease. Kanjanasopa et al. (2011) found that samples of marine products such as blood clams found in the south coast of Thailand are positively contaminants by $V$. parahaemolyticus, a bacteria that cause foodborne disease, and $30 \%$ of foodborne disease cases are from bacterial contamination. However, several studies show that the highest outbreaks and mortality in foodborne disease is caused by bacterial infections (Altekruse et al. 2008). Some of the bacteria that cause foodborne disease, including Escherichia, Pseudomonas, and Vibrio. Vibrio spp., makes up of $10-20 \%$ of foodborne diseases cases transmitted through seafood.

Currently, identification of pathogenic Vibrio sp. has been made only by observing the clinical symptoms from the history of disease events, morphological characteristics, physiology, and biochemistry of the bacteria. One way to advance the identification method is by assessing the genetic properties using molecular. Some of the molecular identifications that currently being developed are through molecular markers of PCR-based techniques. The molecular identification of Vibrio taken from the blood clams proposed in this study is based on the 16S rRNA sequence. This research aimed to evaluate Vibrio content in blood clamps found in coastal areas in Bantul, Yogyakarta, Indonesia by performing pathogenicity test, morphological and molecular characterization. 


\section{MATERIALS AND METHODS}

\section{Sample collection}

Blood clam samples were collected from three locations at Bantul beach area, Yogyakarta, Indonesia, namely Depok, Goa Cemara, and Kuaru Beaches. Nine individuals from each beach were collected and stored in a cooling box containing ice cubes until arriving in the laboratory (Widyowati 2008).

\section{Isolation of Vibrio}

The clam samples were crushed using a mortar, 5 gram of this was stored into a test tube and diluted using $9 \mathrm{~mL}$ of aquadest and diluted in three concentrations, $10^{-2}$ for the second and $10^{-3}$ for the third. Then $0.1 \mathrm{~mL}$ was taken from each dilution and spread using spread plate techniques on Thiosulfate Citrate Bile Salt Sucrose Agar (TCBS) that is commonly used in microbiology laboratories to isolates Vibrio species. Each dilution series was spread into three Petri dishes. All Petri dishes then were incubated at $37^{\circ} \mathrm{C}$ for two days in an upside-down position. The growing colonies were then re-isolated into TCBS media and incubated at $37^{\circ} \mathrm{C}$ for colony purification. Vibrio single colony were re-isolated and grown on TCBS media with an incubation temperature of $37^{\circ} \mathrm{C}$ for 18 hours until the pure culture was obtained (Ilmiah et al. 2012).

\section{Determination of morphology colony of Vibrio isolated from blood clams}

The Vibrio colony that has already grown in TCBS media and incubated was then morphologically observed for its colony color, colony size, colony edge and elevation (the colony surface shape) (Hidayat 2013).

\section{The pathogeny of Vibrio isolated from blood clams}

The pathogenicity of Vibrio in blood clams was evaluated using the hemolysis test with the blood agar plate. The selected isolate was streak-scratched using inoculation needle on the media surface. It was then incubated for 24 hours at room temperature of $37^{\circ} \mathrm{C}$. If the bacterial isolate induced hemolysis activity, a clear zone would form on the media. There are three types of hemolysis, i.e., $\beta$-hemolysis (there is no blood around the grown colonies), $\alpha$-hemolysis (some blood cells found on the hemolysis zone or greenish discoloration around the colonies) and $\varepsilon$-hemolysis (no hemolysis) (Mailoa and Setha 2011)

\section{Molecular characterization}

The bacterial genomic DNA extraction was carried out using Presto ${ }^{\mathrm{TM}}$ Mini gDNA Bacteria kit (GeneAid). Sample of $2 \mu \mathrm{L}$ of genomic DNA was added with aqua dest until the volume was $200 \mu \mathrm{L}$ for 100 times dilution. Then the DNA was transferred into the bio-photometer cuvet. Stamps bio-photometer will read the absorbance of samples with a bio-photometer at $\lambda 260 \mathrm{~nm}$ and $\lambda 280 \mathrm{~nm}$. DNA quality related to the purity of protein contaminants can be seen from the ratio of absorbance of DNA suspension at wavelength $\lambda 260 \mathrm{~nm}$ and $\lambda 280 \mathrm{~nm}$. The OD260/280 ratio between 1.8-2.0 shows that DNA is relatively pure and free from contaminant (Ningsih et al. 2017). Predenaturation process was carried out at a temperature of $95^{\circ} \mathrm{C}$ for 1 minute. Denaturation at $95^{\circ} \mathrm{C}$ for 15 seconds. Annealing at $55^{\circ} \mathrm{C}$ for 15 seconds. Extension or elongation was carried out at $72^{\circ} \mathrm{C}$ for 10 seconds. Final extension at $72^{\circ} \mathrm{C}$ for 5 minutes. The process of denaturation, annealing, and elongation each consist of 25 cycles. Then was stirred in the freezer box at $-20^{\circ} \mathrm{C}$ and checked using electrophoresis (Marchesi et al. 1998; Stephanie and Waturangi 2011)

\section{Sequencing and phylogenetic analysis}

PCR product of $16 \mathrm{~S}$ rRNA gene from colonies were sequenced in Genetika Sains (Jakarta) and result were compared with 16S rRNA sequences obtained from Genbank using BLAST. Phylogenetic tree was constructed using MEGA-X software based on neighbor-joining analysis with the Jukes-Cantor model and the bootstraps method.

\section{RESULTS AND DISCUSSION}

\section{Morphology colony of the Vibrio}

Fifteen bacterial isolates suspected to be Vibrio were obtained from blood clams tissue collected from the coastal area of Bantul (Table 1). Several bacterial isolates were unable to grow on TCBS media indicating that, as a selective medium, TCBS could inhibit a certain type of bacteria from growing. The identification of Vibrio isolates was carried out by colony morphological characterization or visual observation. Vibrio bacteria colonies that grow on TCBS media would vary in color, including green, yellow, transparent green, orange, and bluish green. According to Mailoa and Setha (2011), the green color of Vibrio colony is due to the nature of the Vibrio which is unable to ferment sucrose while the yellow colony is able to ferment sucrose and is able to reduce $\mathrm{pH}$ on TCBS media. The colony shape is circular, the colony edge is entire, and the colony elevation is various (law, convex, and effuse) (Ihsan and Retnaringrum 2017). TCBS plates were examined for the presence of either yellow color, rounded shape, 2-3 $\mathrm{mm}$ in diameter colonies (suspect: V. cholera, V. fluvialis or V. alginolyticus) or green in color, rounded shape and 2-3 mm in diameter (suspect: V. parahaemolyiticus or V. vulnificus).

The variation of the colony's color is likely due to several factors including abiotic factors (factors affecting Vibrio to maintain their survival) namely temperature, conductivity, acidity $(\mathrm{pH})$, dissolved oxygen and total organic matter that was acting as host. In different condition/place, the Vibrio's diversity will also be different according to the growing needs. Besides the abiotic factor, the biotic factors also affect the competition for food and interactions between Vibrio organisms or other species (Mudatsir 2007).

\section{Pathogenicity of bacterial isolates}

The hemolysis test of 15 isolates using blood agar showed that five isolates indicated positive hemolysis activity where four isolates indicated $\beta$-hemolysis, and one isolate indicated $\alpha$-hemolysis (Table 2). 
Table 1. Colony morphological characteristics of 15 bacterial isolates obtained from blood clams (Anadara granosa)

\begin{tabular}{|c|c|c|c|c|c|c|}
\hline Location & $\begin{array}{l}\text { Isolate } \\
\text { code }\end{array}$ & Colony shape & Colony elevation & Colony size (mm) & Colony edge & Colony color \\
\hline \multirow[t]{4}{*}{ Depok beach } & $\mathrm{P}_{1} \mathrm{~S}_{1-1 \mathrm{aK}}$ & Circular & Convex & 4 & Entire & Yellow \\
\hline & $\mathrm{P}_{1} \mathrm{~S}_{1}-1 \mathrm{aH}$ & Circular & Convex & 2 & Entire & Transparent Green \\
\hline & $\mathrm{P}_{1} \mathrm{~S}_{2}-1 \mathrm{aK}$ & Circular & Flat & 2 & Entire & Yellow \\
\hline & $\mathrm{P}_{1} \mathrm{~S}_{2}-1 \mathrm{aH}$ & Circular & Umbonate & 2 & Entire & Green \\
\hline \multirow[t]{6}{*}{ Goa Cemara beach } & $\mathrm{P}_{2} \mathrm{~S}_{1}-1 \mathrm{aK}$ & Circular & Convex & 3 & Entire & Yellow \\
\hline & $\mathrm{P}_{2} \mathrm{~S}_{1}-1 \mathrm{bK}$ & Circular & Flat & 4 & Entire & Yellow \\
\hline & $\mathrm{P}_{2} \mathrm{~S}_{2}-1 \mathrm{aK}$ & Circular & Raised & 2 & Entire & Shiny Yellow \\
\hline & $\mathrm{P}_{2} \mathrm{~S}_{2}-1 \mathrm{aH}$ & Circular & Raised & 2 & Entire & Dark Green \\
\hline & $\mathrm{P}_{2} \mathrm{~S}_{2}-1 \mathrm{bH}$ & Circular & Convex & 2 & Entire & Dark Green \\
\hline & $\mathrm{P}_{2} \mathrm{~S}_{2}-1 \mathrm{aHB}$ & Circular & Convex & 2 & Entire & Bluish Green \\
\hline \multirow[t]{5}{*}{ Kwaru beach } & $\mathrm{P}_{3} \mathrm{~S}_{1}-1 \mathrm{aH}$ & Circular & Convex & 2 & Entire & Green \\
\hline & $\mathrm{P}_{3} \mathrm{~S}_{1}-1 \mathrm{aK}$ & Circular & Flat & 3 & Entire & Dark Yellow \\
\hline & $\mathrm{P}_{3} \mathrm{~S}_{1}-1 \mathrm{bK}$ & Circular & Convex & 4 & Entire & Yellow \\
\hline & $\mathrm{P}_{3} \mathrm{~S}_{2}-1 \mathrm{aK}$ & Circular & Raised & 3 & Entire & Yellow \\
\hline & $\mathrm{P}_{3} \mathrm{~S}_{2}-1 \mathrm{aH}$ & Circular & Convex & 2 & Entire & Green \\
\hline
\end{tabular}

Note: P=Location (1, Depok; 2 Goa Cemara beach; 3, Kwaru beach), S=Condition (1, Fresh; not Fresh)

Table 2. Results of hemolysis test of Vibrio isolates

\begin{tabular}{llll}
\hline Isolate code & $\begin{array}{l}\text { Hemolysis } \\
\text { zone* }\end{array}$ & $\begin{array}{l}\text { Hemolysis } \\
\text { zone }(\mathbf{m m})\end{array}$ & $\begin{array}{l}\text { Hemolysis } \\
\text { type }\end{array}$ \\
\hline $\mathrm{P}_{1} \mathrm{~S}_{1}-1 \mathrm{aK}$ & - & - & - \\
$\mathrm{P}_{1} \mathrm{~S}_{1}-1 \mathrm{aH}$ & - & - & - \\
$\mathrm{P}_{1} \mathrm{~S}_{2}-1 \mathrm{aK}$ & - & - & - \\
$\mathrm{P}_{1} \mathrm{~S}_{2}-1 \mathrm{aH}$ & - & - & - \\
$\mathrm{P}_{2} \mathrm{~S}_{1}-1 \mathrm{aK}$ & +++ & 1.87 & $\beta$-hemolysis \\
$\mathrm{P}_{2} \mathrm{~S}_{1}-1 \mathrm{bK}$ & - & - & - \\
$\mathrm{P}_{2} \mathrm{~S}_{2}-1 \mathrm{aK}$ & +++ & 1.72 & $\beta$-hemolysis \\
$\mathrm{P}_{2} \mathrm{~S}_{2}-1 \mathrm{aH}$ & - & - & - \\
$\mathrm{P}_{2} \mathrm{~S}_{2}-1 \mathrm{bH}$ & +++ & 1.55 & $\beta$-hemolysis \\
$\mathrm{P}_{2} \mathrm{~S}_{2}-1 \mathrm{aHB}$ & - & - & - \\
$\mathrm{P}_{3} \mathrm{~S}_{1}-1 \mathrm{aH}$ & +++ & 1.57 & $\beta$-hemolysis \\
$\mathrm{P}_{3} \mathrm{~S}_{1}-1 \mathrm{aK}$ & - & - & - \\
$\mathrm{P}_{3} \mathrm{~S}_{1}-1 \mathrm{bK}$ & - & - & $\alpha$-hemolysis \\
$\mathrm{P}_{3} \mathrm{~S}_{2}-1 \mathrm{aK}$ & ++ & 1.98 & - \\
$\mathrm{P}_{3} \mathrm{~S}_{2}-1 \mathrm{aH}$ & - & - & \\
\hline Note* Hemolysis test was qualitatively done: +++: showing very \\
strong lysed zone, ++ +: showing medium lysed zone, +: showing \\
weak lysed zone & &
\end{tabular}

Hemolysin is a protein that can damage cell membranes and lyse red blood cells. Hemolysin spreads through blood circulation (Mangunwardoyo et al. 2009). The ability to produce extracellular toxins in the form of hemolysin is an indicator in determinating the virulence of Vibrio. The agar media with high salt concentrations made by Wagatzuma is used to detect Vibrio hemolytic activity (Figure 1).

The ability of $\beta$-hemolysis strains to multiply is faster in the gastrointestinal tract compared to $\alpha$-hemolysis. This is an important factor in determining the virulence of these bacteria. While enterotoxin production by both $\beta$-hemolysis and $\alpha$-hemolysis strain determines its pathogenic characteristic. B-hemolysis strain is more resistant than $\alpha$ hemolysis. Vibrio that contains $\beta$-hemolysis are pathogenic to humans, but some bacteria are not invasive and do not enter the blood circulation and remain in the intestine. Bacteria containing $\beta$-hemolysis can produce enteroctine. Belkin and Collwell (2005) reported that the clear zone activity formed in the agar blood media shows the activity of $\beta$-hemolysin caused by thermostable direct hemolysin $(T D H)$ gene. This gene determines virulence factors. Vibrio having TDH gene were mostly found in the aquatic environment. This is in accordance with the statement of Raghunath (2015), which shows that pathogenic Vibrio has low oxygen and high levels of organic components in the aquatic environment. This TDH gene and TRH gene (the thermostable direct hemolysin-related hemolysin) are active because there is a specific gene in Vibrio, that is the tox $R$ gene. The work of the toxR gene is to activate other genes to produce toxins.

\section{Identities of the Vibrio species based on the 16S rRNA encoding gene}

Bacterial isolates are considered as different species if the similarities of rRNA sequence are lower than $97 \%$ (Stackebrandt and Goebel 1994). The taxonomy of modern bacteria is based on the 16S rRNA gene equation approach that $95 \%$ equation threshold for genus and $98,5 \%$ can be said as a species (Rossi-Tamisier et al. 2015).

Diform the database found in GenBank 10 out of 15 candidates (Table 3) were identified as Vibrio, then five other isolates were similar to bacteria from the genus Rothia, Aeromonas, and Staphylococcus. TCBS is highly selective media for Vibrio by providing a specific environment and source that only suitable for Vibrio. The presence of other species in this TCBS agar is most likely that they have a very similar environment requirement to grow as Vibrio. This is also the reason why further biochemical and molecular identification of grown isolates from TCBS media is needed. In this research, we used $16 \mathrm{~S}$ rRNA encoding gene for isolates identification (Figure 2). 


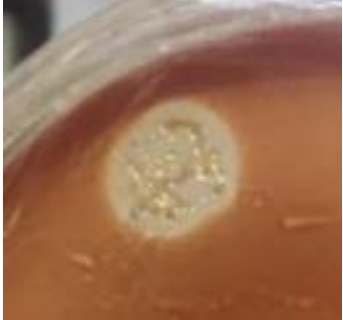

A

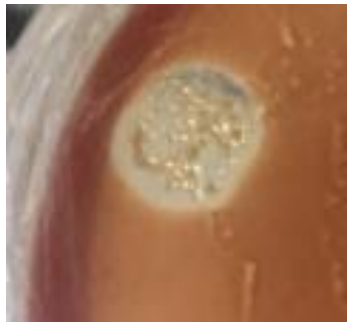

B

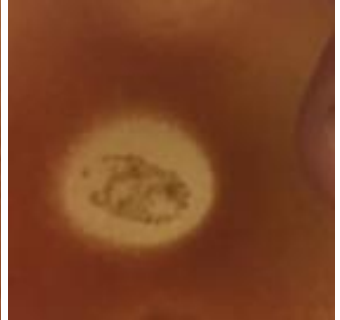

C

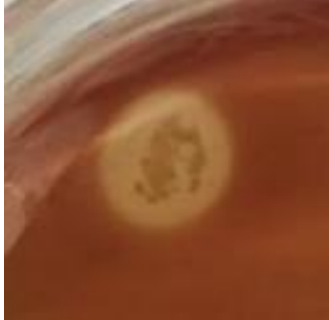

D

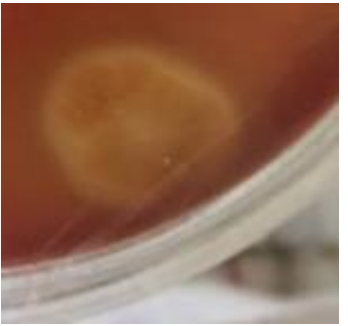

$\mathbf{E}$

Figure 1. Morphological characters of the colony as resulted from the hemolysis test of Vibrio isolates. $\beta$-hemolysis: $\mathrm{A}$. $\mathrm{P}_{2} \mathrm{~S}_{2}-1 \mathrm{bH}, \mathrm{B}$. $\mathrm{P}_{2} \mathrm{~S}_{2}-1 \mathrm{aK}, \mathrm{C} . \mathrm{P}_{3} \mathrm{~S}_{1}-1 \mathrm{aH}, \mathrm{D} . \mathrm{P}_{2} \mathrm{~S}_{1}-1 \mathrm{Ak}$; as well as $\alpha$-hemolysis: E. $\mathrm{P}_{3} \mathrm{~S}_{2}-1 \mathrm{aK}$

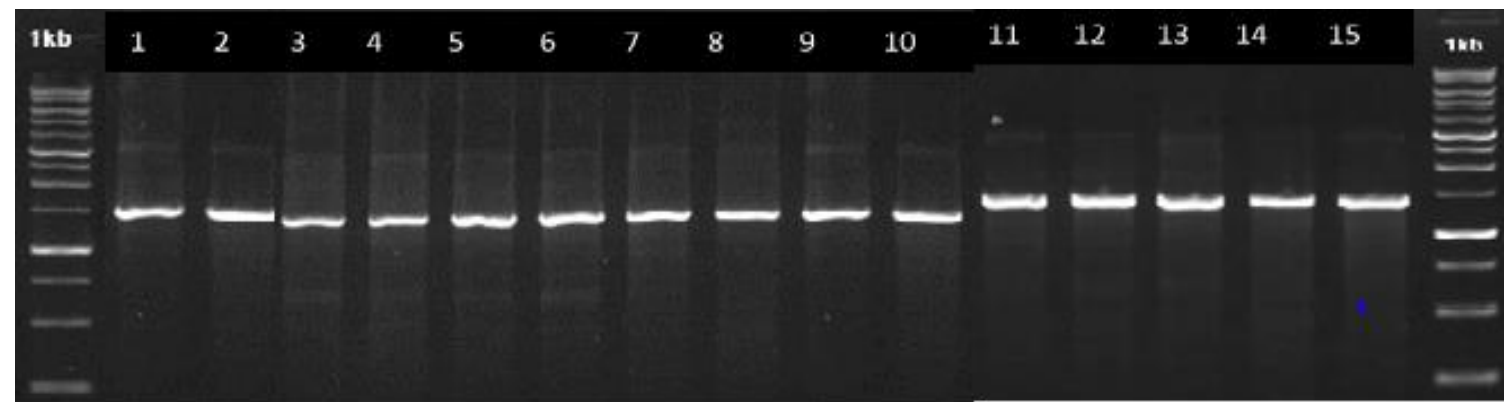

Figure 2. The electrophoresis gel of the $16 \mathrm{~S}$ rRNA gene from the isolate amplified using primary $63 \mathrm{~F}$ and $1387 \mathrm{~F}$ from blood clams. Note: 1. $\mathrm{P}_{1} \mathrm{~S}_{1}-1 \mathrm{aK}, 2$. $\mathrm{P}_{1} \mathrm{~S}_{1}-1 \mathrm{aH}, 3$. $\mathrm{P}_{1} \mathrm{~S}_{2}-1 \mathrm{aK}, 4$. $\mathrm{P}_{1} \mathrm{~S}_{2}-1 \mathrm{aH}, 5$. $\mathrm{P}_{2} \mathrm{~S}_{1}-1 \mathrm{aK}, 6 . \mathrm{P}_{2} \mathrm{~S}_{1}-1 \mathrm{bK}, 7$. $\mathrm{P}_{2} \mathrm{~S}_{2}-1 \mathrm{aK}, 8 . \mathrm{P}_{2} \mathrm{~S}_{2}-1 \mathrm{aH}, 9$. $\mathrm{P}_{2} \mathrm{~S}_{2}-1 \mathrm{bH}, 10$. $\mathrm{P}_{2} \mathrm{~S}_{2}-$ $1 \mathrm{aHB}, 11 . \mathrm{P}_{3} \mathrm{~S}_{1}-1 \mathrm{aH}, 12 . \mathrm{P}_{3} \mathrm{~S}_{1}-1 \mathrm{aK}, 13 . \mathrm{P}_{3} \mathrm{~S}_{1}-1 \mathrm{bK}, 14 . \mathrm{P}_{3} \mathrm{~S}_{2}-1 \mathrm{aK}, 15 . \mathrm{P}_{3} \mathrm{~S}_{2}-1 \mathrm{aH}$

Table 3. The identity of Vibrio species based on the 16S rRNA sequence isolated from blood clams in Yogyakarta beaches area

\begin{tabular}{|c|c|c|c|c|c|c|c|c|}
\hline Location & Isolate code & Description & $\begin{array}{l}\text { Max } \\
\text { score }\end{array}$ & $\begin{array}{l}\text { Total } \\
\text { score }\end{array}$ & $\begin{array}{l}\text { Quey } \\
\text { cover }\end{array}$ & $\begin{array}{c}\mathbf{E} \\
\text { value }\end{array}$ & Access No. & Ident \\
\hline \multirow[t]{4}{*}{ Depok Beach } & $\mathrm{P}_{1} \mathrm{~S}_{1}-1 \mathrm{aK}$ & Aeromonas enterpelogeneses & 1934 & 19262 & $90 \%$ & 0.0 & KX980472.1 & $97 \%$ \\
\hline & $\mathrm{P}_{1} \mathrm{~S}_{1}-1 \mathrm{aH}$ & Vibrio parahaemolitucus strain HH101313 & 2156 & 2156 & $92 \%$ & 0.0 & MG386398.1 & $98 \%$ \\
\hline & $\mathrm{P}_{1} \mathrm{~S}_{2}-1 \mathrm{aK}$ & Vibrio alginolyticus strain HH101307 & 2154 & 2154 & $92 \%$ & 0.0 & MG386392.1 & $98 \%$ \\
\hline & $\mathrm{P}_{1} \mathrm{~S}_{2}-1 \mathrm{aH}$ & Vibrio parahaemolyticus strain SC2 & 1951 & 1951 & $88 \%$ & 0.0 & MK308579.1 & $98 \%$ \\
\hline \multirow[t]{6}{*}{ Goa Cemara Beach } & $\mathrm{P}_{2} \mathrm{~S}_{1}-1 \mathrm{aK}$ & Vibrio natrigens strain $\mathrm{Xmb} 012$ & 1951 & 1951 & $88 \%$ & 0.0 & KT986142.1 & $98 \%$ \\
\hline & $\mathrm{P}_{2} \mathrm{~S}_{1}-1 \mathrm{bK}$ & Vibrio azureus strain Xmb005 & 1951 & 1951 & $91 \%$ & 0.0 & KT986135.1 & $98 \%$ \\
\hline & $\mathrm{P}_{2} \mathrm{~S}_{2}-1 \mathrm{aK}$ & Vibrio alginolyticus $\mathrm{CZN}-16 \mathrm{~S}$ & 1821 & 1821 & $98 \%$ & 0.0 & KR347254.1 & $98 \%$ \\
\hline & $\mathrm{P}_{2} \mathrm{~S}_{2}-1 \mathrm{aH}$ & Vibrio parahaemolyticus strain VP-ABTNL & 2159 & 2159 & $92 \%$ & 0.0 & MG589511.1 & $98 \%$ \\
\hline & $\mathrm{P}_{2} \mathrm{~S}_{2}-1 \mathrm{bH}$ & Vibrio diabolicus strain WAB2224 & 2154 & 2154 & $91 \%$ & 0.0 & MH169294.1 & $98 \%$ \\
\hline & $\mathrm{P}_{2} \mathrm{~S}_{2}-1 \mathrm{aHB}$ & Aeromonas dhakensis & 1934 & 1934 & $90 \%$ & 0.0 & MF953268.1 & $97 \%$ \\
\hline \multirow[t]{5}{*}{ Kwaru Beach } & $\mathrm{P}_{3} \mathrm{~S}_{1}-1 \mathrm{aH}$ & Rothia endhopytica strain $\mathrm{CF} 22$ & 1951 & 1951 & $89 \%$ & 0.0 & KX062009.1 & $99 \%$ \\
\hline & $\mathrm{P}_{3} \mathrm{~S}_{1}-1 \mathrm{aK}$ & Vibrio cholerae strain TP & 2156 & 2156 & $92 \%$ & 0.0 & AY494843.1 & $98 \%$ \\
\hline & $\mathrm{P}_{3} \mathrm{~S}_{1}-1 \mathrm{bK}$ & Vibrio neocaledonicus strain SCSIO 43731 & 1951 & 1951 & $88 \%$ & 0.0 & MH283815.1 & $98 \%$ \\
\hline & $\mathrm{P}_{3} \mathrm{~S}_{2}-1 \mathrm{aK}$ & Aeromonas caviae strain $65 \mathrm{H} 8 \mathrm{M}$ & 1934 & 19013 & $90 \%$ & 0.0 & AP019195.1 & $97 \%$ \\
\hline & $\mathrm{P}_{3} \mathrm{~S}_{2}-1 \mathrm{aH}$ & Staphylococcus sciuri strain SS3 & 2178 & 2178 & $91 \%$ & 0.0 & MG593973.1 & $98 \%$ \\
\hline
\end{tabular}

Note: P: Location of beaches and S: Condition blood clams (Fresh and not fresh)

$\mathrm{P}_{2} \mathrm{~S}_{2}-1 \mathrm{aK}$ and $\mathrm{P}_{1} \mathrm{~S}_{2}-1 \mathrm{aK}$ isolates were $98 \%$ similar to Vibrio alginolitycus; these bacteria are pathogenic and are halophilic bacteria. In TCBS media, these Vibrio bacteria form yellow colonies with $0.8-1.2 \mathrm{~cm}$ in diameter (Buwono 2004), and they can ferment glucose, lactose, sucrose, and maltose. $V$. alginolyticus is reported to be a pathogen but the infection and transmission causing foodborne disease is still being studied with allegations of transmission pathways from seawater that becoming parasites in marine species (seafood) or as opportunistic pathogens (Ben Kahla-Nakbi et al. 2007). V. alginolyticus has many virulence genes which are also found in other Vibrio species that live in seawater environments. Its contribution accelerates the development of wounds, intestinal diseases, and sepsis in humans (Ennaji and Cohen 2013). The deadly toxin produced by $V$. alginolyticus is alkaline serine protease (Felix et al. 2011). V. algynolyticus is proven to cause gastroenteritis and peritonitis in foodborne disease 
patient. Besides, it also causes infection and death in immunocompromised patients (Campanelli et al. 2008). Vibrio algynolyiticus also infects in a short period of time.

$\mathrm{P}_{2} \mathrm{~S}_{2}-1 \mathrm{aH}$ and $\mathrm{P}_{1} \mathrm{~S}_{2}-1 \mathrm{aH}$ isolate has $98 \%$ similarities with Vibrio parahaemolyiticus. The colonies have a diameter of 3-5 mm with greenish-blue color with a dark green spot in the middle. The characteristic of $V$. parahaemolyticus (Richie 2005) has flagella, and it distributed on tropical beaches with fermentative biochemical of mining, lactose, sucrose, and positive gas production $V$. parahaemolyticus is a pathogenic bacteria that produce hemolysin called Thermostable Direct Hemolysin (TDH) and Thermostable Direct HemolysinRelated Hemolysin (TRH). TDH is known as virulence factor because it has $\beta$ hemolysis activity that leads to gastroenteritis in humans (Yennie et al. 2015). The level of virulence of $V$. parahaemolyticus does not depend on the amount of $V$. parahaemolyticus, instead very dependent on the toxin produced by the gene (Sujeewa et al. 2009). This TDH and TRH gene will act as toxic in the human digestive tracts. Thus, in certain numbers can cause dysentery (Anses 2012).

$\mathrm{P}_{3} \mathrm{~S}_{1}-1 \mathrm{aK}$ bacterial isolate has $98 \%$ similarities with Vibrio cholerae. V. cholerae is a bacterium that can grow in various media or selective media containing mineral salts and asparagine as a source of carbon and nitrogen. If it is grown in TCBS media, it will appear in the yellow colony. $V$. cholerae is a pathogenic bacterium and triggers foodborne disease in human through the digestive system (fecal-oral). $V$. cholerae increases the secretion of enterotoxins in the body and stimulates adenyl cyclase activity in intestinal cells. This results in the conversion of adenosine triphosphate (ATP) to cyclic adenosine monophosphate (cAMP) which causes electrolyte secretion into the intestinal cavity. It results in a large amount of fluid loss and electrolyte imbalance. This bacterial infection can result in gastroenteritis characterized by bloody bowel movements accompanied by vomiting blood. $V$. cholerae is not invasive and does not enter the bloodstream but persists in the intestinal tract. It enters the body with food and drink that positively contaminated by $V$. cholerae. After passing gastric acid, this bacterium will produce two virulence factors that cause a disease called cholera. The toxin is in the form of coregulated pilus toxin (TCP) and cholerae toxin (CT). Seafood is the most common source of $V$. cholerae contamination. The common preparation of seafood to prevent foodborne disease is heat cooking that kills all the bacteria (Paydar 2013).

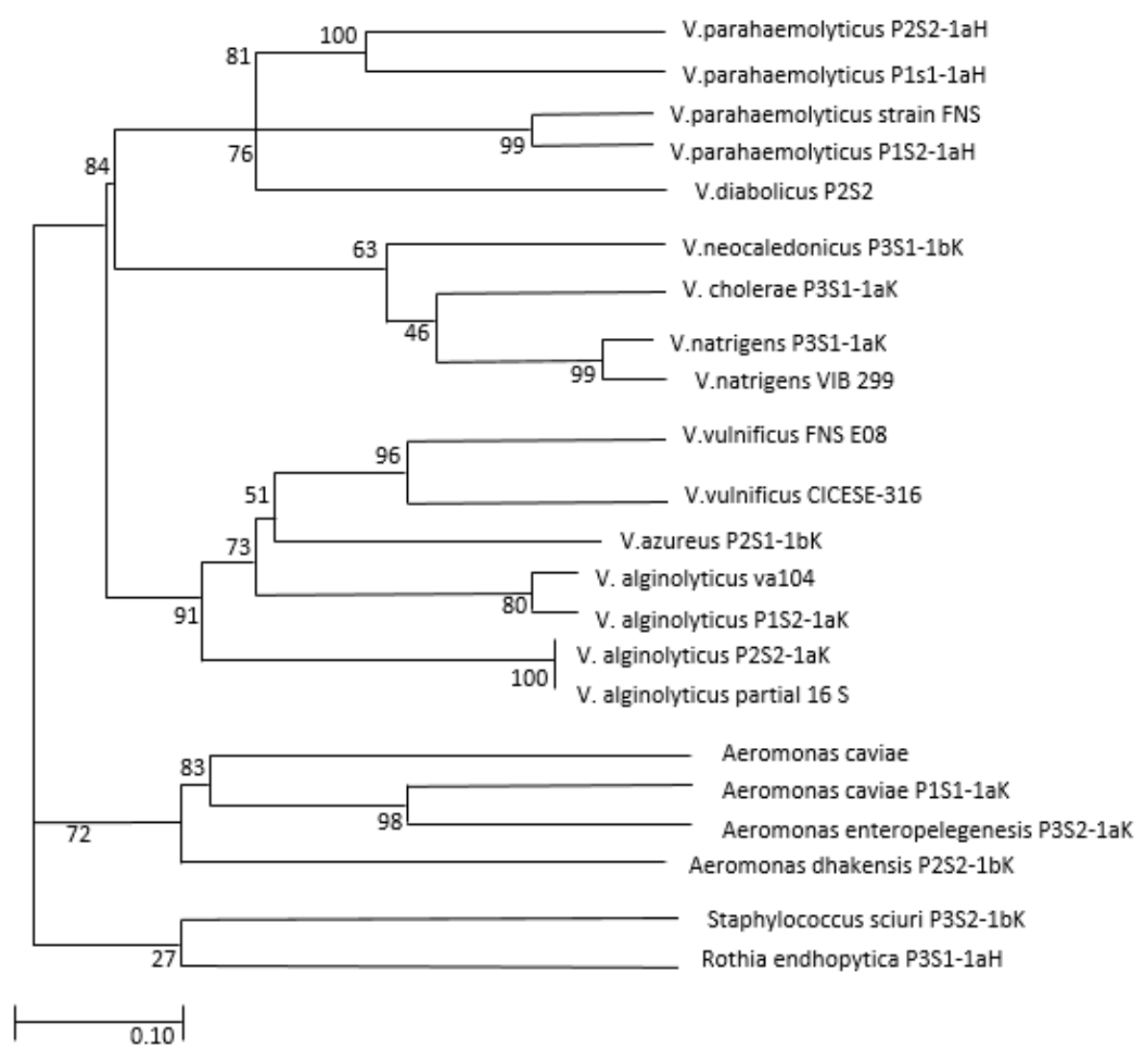

Figure 3. Vibrio spp. isolated from blood clams in Yogyakarta, Indonesia beaches area. Note: $\mathrm{P}_{1} \mathrm{~S}_{1}-1 \mathrm{aK}, \mathrm{P}_{1} \mathrm{~S}_{1}-1 \mathrm{aH}, \mathrm{P}_{1} \mathrm{~S}_{2}-1 \mathrm{aK}, \mathrm{P}_{1} \mathrm{~S}_{2-}$ $1 \mathrm{aH}, \mathrm{P}_{2} \mathrm{~S}_{1}-1 \mathrm{aK}, \mathrm{P}_{2} \mathrm{~S}_{1}-1 \mathrm{bK}, \mathrm{P}_{2} \mathrm{~S}_{2}-1 \mathrm{aK}, \mathrm{P}_{2} \mathrm{~S}_{2}-1 \mathrm{aH}, \mathrm{P}_{2} \mathrm{~S}_{2}-1 \mathrm{bH}, \mathrm{P}_{2} \mathrm{~S}_{2}-1 \mathrm{aHB}, \mathrm{P}_{3} \mathrm{~S}_{1}-1 \mathrm{aH}, \mathrm{P}_{3} \mathrm{~S}_{1}-1 \mathrm{aK}, \mathrm{P}_{3} \mathrm{~S}_{1}-1 \mathrm{bK} \mathrm{P}_{3} \mathrm{~S}_{2}-1 \mathrm{aK} \mathrm{P}_{3} \mathrm{~S}_{2}-1 \mathrm{aH}$ (*): Vibrio isolate from blood clams found in Yogyakarta, Indonesia. V. parahaemolyticus strain FNS C08, V. natrigens strain VIB 299, V. vulnificus strain FNS E08, Aeromonas caviae, $V$. vulnificus strain FNS E08, V. vulnificus strain CICESE-316, V. vulnificus strain FNS E08, $V$. alginolyticus partial 16S, V. alginolyticus strain va104: Isolate from finding previously in seafood are the cause of foodborne disease 
$\mathrm{P}_{3} \mathrm{~S}_{1}-1 \mathrm{bK}$ isolate has a $98 \%$ similarity with Vibrio neocaledonicus. This bacterium is the latest strain identified in Vibrio. It is a gram-negative bacterium and is usually found in water with extreme conditions. In contrast to other Vibrios, Vibrio neocaldonicus does not cause foodborne disease but known for its role in preventing metal degradation due to corrosion. It inhibits metal electrochemical corrosion by consuming oxygen through electron-transport proteins. This bacterium has been developed in China since 2014 because it is natural, nontoxic and effective in controlling the corrosion process and does not damage the marine ecosystem (Moradi et al. 2015)

$\mathrm{P}_{2} \mathrm{~S}_{1}-1 \mathrm{bK}$ isolate has a $98 \%$ similarity with Vibrio azureus bacteria. This bacterium has similarity with $V$. parahaemolyiticus. It is luminous and translucent and has positive oxidation. In the sea, it is formed on sea agar with usually $5-7 \mathrm{~mm}$ in size. Vibrio azureus is positive for indole glucose and amygdaline production and fermentation. Based on the 16S rRNA gene $V$. azureus strains forms a cluster on Vibrio harveyi (Yoshizawa et al. 2009).

$\mathrm{P}_{2} \mathrm{~S}_{2}-1 \mathrm{bH}$ isolate has $98 \%$ similarities with Vibrio diabolicus. This bacterium can cause pathogenic foodborne disease, and it lives in the deep sea. This species is very close to Vibrio alginolyticus and $V$. parahaemolyticus which are living in coastal areas. That $V$. diabolicus and Vibrio antiquarius are the same species. This species is a new member of Vibrio. $V$. diabolicus is confirmed to produces $\beta$-lactamase based on a cefinase test. It shows resistance to penicillin, ampicillin, and cephalothin and is susceptible to carbenicillin. This bacterium has a specific virulence gene called AcfA for colicin production. Colicin is a protein that stimulates the production of Tox $R$, Tox $S$, Zonulaa occludens toxins (Zot) and Ace. This gene makes a defense of toxic and metalloid and is resistant to antibiotics (Turner et al. 2018).

The limitation of the $16 \mathrm{~S}$ rRNA equation used to identify species is only a big estimate. Several different species can have similarities up to $99 \%$ of the same sequence, as in Bacillus globiporus and Bacillus psychrophilus or with the same strain can have different copies of genes with a difference of $5 \%$ in some gene regions for example in Escherichia coli K12 (Nguyen et al. 2016 ).

The $\mathrm{p}$ of the Vibrio species found in this research and other Vibrio references was analyzed using Mega-X software. All species found in this research are closely related to other Vibrio species that have previously identified in Genbank (Figure 3).

Phylogenetic tree base on the contented gene sequences of the 16S rRNA (1500bp). This tree combines the result of both the neighbor-joining (NJ) method. Numbers at nodes denote the level of bootstrap support $(\%)$ based on 500 replicates. The root the Vibrios phylogenetic tree within the genus, we first reconstructed a phylogenetic tree from the closed genomes of 15 strains belonging to seven Vibrio species (V. cholerae, V. alginolyticus, V. parahaemolyticus, $V$. diaolicus, $V$. neocalendonicus, $V$. natrigens, and $V$. azureus).

\section{REFERENCES}

Altekruse SF, Hyman FH, Klontz KC, Timbo BT, Tolleson LK. 2008. Foodborne disease bacterial infection in an individual with the human immunodeficiency virus. South Med J 87: 169-173.

Anses. 2012. Vibrio parahaemolyticus Family Vibrionaceae, genus Vibrio Bacterium. Data Sheet on Foodborne disease Biological hazzard. Agence Nationale de securite Sanitaire Alimentation, Environment, Travail. Maisons-Alfort Cedex, Paris.

Belkin S, Colwell RR. 2005. Ocean and Health: Pathogens in the Marine Environment. Springer, New York.

Ben Kahla-Nakbi A, Besbes A, Chaieb K, Rouabhia M, Bakhrouf A. 2007. Survival of Vibrio alginolyticus in seawater and retention of virulence of its straved cells. Mar Environ Res 64: 469-478.

Buwono D. 2004. Jenis Penyakit pada Ikan (Finfish) Budidaya Air Payau. Balai Besar Pengembangan Budidaya air Payau Jepara. Departemen Perikanan dan Kelautan, Jakarta. http: //www. dkp. go. id/content. php. [Indonesian]

Campanelli A, Sanchez-Pollita S, Saurat JH. 2008 Ulceration cutanee apres morsure de poulpe: Infection a Vibrio alginolyticus un pathogene emergent. Annal Dermatol Venerol 135: 225-227.

Ennaji M, Cohen N. 2013. Vibrio alginolyticus: An emerging pathogen of foodborne disease. Intl J Sci Technibiol 2 (4): 302-309.

Felix F, Nogroho TT, Silalahi S, Oktavia Y. 2011. Screening of Indonesian original bacterial Vibrio sp. as a cause of shrimp diseases based on 16S ribosomal DNA-technique. Trop Mar Sci Technol J 3 (2): 85-99.

Hidayat ARS. 2013. Karakaterisasi bakteri Genus Vibrio dari ikan kerapu (Plectropomus sp.). Jurnal Biogenesis 1 (2): 141-143. [Indonesian]

Ihsan B, Retnaringrum E. 2017. Isolasi dan Identifikasi Bakteri Vibrio sp pada Kerang Kapah (Meretrix meretrix) di Kabupaten Trenggalek. Borneo Harpodon Journal 10 (1): 23-27. Indonesian]

Ilmiah, Sukenda, Widanarni, Enang H. 2012. Isolation and characterization of pathogenic Vibrio on Tiger grouper Epinephelus fuscoguttatus. J Akuakultur Indonesia 11 (1): 28-37. [Indonesian]

Kanjanasopa D, Pimpa B, Chowpongpang S. 2011. Occurrence of Vibrio parahaemolyticus in cockle (Anadara granosa) harvested from the south coast of Thailand. Songklanakarin J Sci Technol 33 (3): 295300 .

Mailoa MN, Setha B. 2011. Karakteristik patogenitas Vibrio sp. diisolasi dari lendir sidat (Anguilla sp). Jurnal Kedokteran dan Kesehatan 4 (1): 42-48. [Indonesian]

Mangunwardoyo W, Ismayasari R, Riani E. 2009. Aktivitas kitinase, lesitinase, dan hemolisin isolat dari bakteri ikan nila (Oreochromis niloticus Lin.) yang dikultur dalam keramba jaring apung Waduk Jatiluhur, Purwakarta. Jurnal Riset Akuakultur 4 (2): 257-265. [Indonesian]

Marchesi JR, Sato T, Weighman AJ, Martin TA, Fry JC, Himpm SJ, Wade WG. 1998. Design and evaluation of useful bacterium specific PCR primer that amplify genes coding for bacterial 16S rRNA. Appl. Environ Microbiol 63: 795-764.

Moradi I, Song Z, Tao X. 2015. Introducing a novel bacterium, Vibrio neocaledonicus with the highest corrosion inhibition efficiency. $\begin{array}{llll}\text { Electrochem } & \text { Commun } & \end{array}$ 10.1016/j.elecom2014.12.007

Mudatsir. 2007. Faktor-faktor yang mempengaruhi kehidupan mikroba dalam air. Med Syiah Kuala J 7 (1) 23-30. [Indonesian]

Nguyen Nam-Phuong, Tandy W, Mihai P, Bryan W. 2016. A Perspective on 16S rRNA operational taxonomic unitclustering using sequence similarity. Nat Partner J 2: 1-8.

Ningsih HU, Prakarsa TBP, Margawati ET. Koleksi DNA dan Konfirmasi Marka ETH10 Pengkode Sifat Pertumbuhan pad Sapi Pasundan. Biotropic: J Trop Biol 1 (1): 9-16. [Indonesian]

Nurjanah, Zulhamsyah, Kustariyah. 2005. Kandungan mineral dan proksimat Kerang Darah (Anadara granosa) yang diambil dari kabupaten boalemo, Gorontalo. Buletin Teknologi Hasil Perikanan 8 (2): 1-4. [Indonesian]

Paydar M. 2013. Isolation and differentiation of Vibrio species from seafood and molecular characterisation of Vibrio parahaemolyticus. [Dissertation]. University of Malaya, Kuala Lumpur.

Raghunath P. 2015. Roles of thermostable direct hemolysin (TDH) and TDH-related hemolysin (TRH) in Vibrio parahaemolyticus. Frontiers Microbiol 5: 8-11. DOI: 10.3389/fmicb.2014.00805 
Richie JP. 2005. Analisis bakteri Vibrio pada udang windu (Penaeus monodon) tambak di Bengkalis Propinsi Riau. [Hon. Thesis]. Faperikan UNRI, Pekanbaru (tidak diterbitkan). [Indonesian]

Rossi-Tamisier M, Benamar S, Raoult D, Fournier PE. 2015. Cautionary tale of Using $16 \mathrm{~S}$ rRNA gene sequence similarity values in identification of human-associated bacterial species. Int J Syst Evol Microbiol 65: 1929-1467.

Stackebrandt E, Goebel BM. 1994. Taxonomic note: a place for DNADNA reassociation and $16 \mathrm{~S}$ rRNA sequence analysis in the present species definition in bacteriology. Intl J Syst Evol Microbiol 44 (4): 846-849.

Stephanie, Waturangi DE. 2011. Distribution of INA bacteria from rainwater and air. Hayati J Biosci 18: 108-112.

Sujeewa AKW, Norrakiah AS, Laina M. 2009. Prevalence of toxic genes of Vibrio parahaemolyticus in shrimps (Penaeus monodon) and culture environment. Intl Food Res J 16: 89-95.
Turner JW, Tallman JJ, Macias A, et al. 2018. Comparative genomic analysis of Vibrio diabolicus and six taxonomic synonyms: A first look at the distribution and diversity of the expanded species. Front Microbiol J. DOI: 10.3389/fmicb.2018.01893.

Widowati R. 2008. Keberadaan bakteri Vibrio parahaemolyticus pada udang yang dijual di Rumah Makan Kawasan Panta Pangandaran. Jurnal Vis Vitalis 1 (1): 9-14.

Yennie Y, Hariyadi RD, Poernomo A. 2015. Prevalensi gen $t d h$ dan $t r h$ Vibrio parahaemolyticus pada udang vaname di wilayah Indramayu, Jawa Barat. Jurnal Pascapanen dan Bioteknologi Kelautan dan Perikanan 10 (1): 61-70. [Indonesian]

Yoshizawa S, Wada M, Kita-Tsukamoto K, Ikemoto E, Yokota A, Kogure K. 2009. Vibrio azureus sp. nov., a luminous marine bacterium isolated from seawater. Intl J Syst Evol Microbiol 59 (7): 1645-1649. 